Original Research Paper

\title{
The Analysis of Value Chain of Beef Cattle Partnership Business Based on Financial Technology
}

\author{
${ }^{1}$ Dwi Yuzaria, ${ }^{2}$ Basril Basyar and ${ }^{2}$ Rusjda Khairati \\ ${ }^{1}$ Department of Social Economics, Faculty of Animal Science, Andalas University, Padang, Indonesia \\ ${ }^{2}$ Department of Animal Science, Andalas University, Padang, Indonesia
}

Article history

Received: 21-12-2019

Revised: $12-02-2020$

Accepted: 18-03-2020

Corresponding Author:

Dwi Yuzaria

Department of Social

Economics, Faculty of Animal

Science, Andalas University

Padang, Indonesia

Email: dyuzaria@ansci.unand.ac.id

\begin{abstract}
Ternak is an online financial technology innovation that connects both farmers and investors with the application available in Plays tore. The aims of this first-year study are: (1) To describe the role of partnership in information technology-based value chains on the formation of beef cattle business value chains, (2) to analyze the role of financial technology-based partnership in livestock business performance in beef cattle value chains, (3) to analyze the cost structure and marketing margin formed in the information technology-based beef cattle value chain. The analysis was carried out by adapting the value chain model with entry points for the analysis of the role of partnerships in the value chain, value chain mapping and value chain performance analysis of each chain. The study reveals that the value chains involved in i-Ternak as a website manager are investors, suppliers, breeders and processors and distributors of cattle and meat. The margin obtained is still low as investors get $7.76 \%$ per 6 months, the biggest chain with margins is meat processed while the lowest is livestock. The largest share of costs is incurred by the processor who also receives the largest share of profit. Cattle fattening $\mathrm{R} / \mathrm{C}$ is 1.14 .
\end{abstract}

Keywords: i-Ternak, Beef Cattle, Partnership, Information System, Value Chain Performance

\section{Introduction}

The development of Information Technology has drastically changed the global business environment. The use of both the internet for product marketing and the development of business networks in the past few decades seems to have surpassed the classical economic concept which suggests that the ownership of production factors is the key to business success. The use of information technology for online marketing through social media (Facebook, Instagram, Twitter, Whatsapp, Blackberry messenger and Others) and web-based products provides information on goods or services more broadly, quickly, efficiently, attractively and in-line with consumer behavior trends in the era of the creative industry today.

Indonesia's current economic growth is good enough to have a direct impact on increasing beef consumption, but it is not accompanied by production growth. Some obstacles such as capital, low human resources, insufficient feed intake are the causes of the case. Facing this obstacle, farmers can now utilize the information technology-based program, i-Ternak. i-Ternak is an online farming application that is accessible from mobile application and website, without having to have land, skills and time to care for livestock. i-Ternakconnects Livestock Market, farmers or Koperasi Ternak and livestock investors. i-Ternakcreates an opportunity for farmers/Koperasi Ternak as cattle nurses with urban communities as investors who want to raise livestock. Is livestock rising profitable? The purpose of this study is to assess the success of livestock through the analysis of value chain performance through the supply chain, market margin and management performances.

Porter (1998) divided value chain activity into two different activities, namely: Primary activity or supply chain activity and secondary activity in the form of a supporting environment. Value chain performance is strongly supported by the performance carried out by actors involved in business activities and supporting environments such as the availability of infrastructure and logistics, the availability of access to information and knowledge and the availability of organizational access. The partnership that is well established creates mutual dependence. The partnership carried out by farmers and other parties can also build work specialization that increases business efficiency, sharing risk, guarantees of 
marketing and can improve the ability of farmers to access information. According to Dahlia and Dian (2015), the use of information technology can improve business transformation through the speed, accuracy and efficiency of information exchange in large numbers. Information technology increases organizational effectiveness and efficiency through the speed of processing, consistency and reliability in handling organizational activities (David, 2006). Salin (2000) said that beef cattle farming business utilizes information technology to facilitate its supply chain. The information technology helps the supply chain function so that partners can track consumer demand at the transaction level in detail. The information technology is also used in the supply chain to monitor partner chain costs so that the functions can be carried out at the most effective level of costs and the revenue is divided appropriately. According to Shipley and Egan (1992), a partnership is an informal relationship where partners effectively recognize and pursue common interests.

Interdependence, flexibility, hope for long-term cooperation and the quality of partnerships in the distribution channel industry are antecedents that influence the strategic integration that has an impact on company performance. The quality of a partnership that is based on trust, justice and equality will spur strategic integration between companies and they tend to view the partnership as a strategic asset and a tool of strategic policy (strategic tool). It is hoped that the better the partnership relationship, the more effective the supply chain management will be and ultimately provide better corporate performance seen from the benefits of each of the chain involved.

A value chain is a pattern that a company used to understand its cost position and to identify ways that can be used to facilitate the implementation of its business-level strategy. The value chain shows how a product moves from the raw material stage to the final customer. Value chain analysis describes the activity relations in and around a company with the company's competitive strength (Porter, 1998). According to Barney and Clark (2007), companies must focus on the resources they have to analyze the strengths and weaknesses of the companies. According to Barney and Clark (2007), the existing resources within the company can be divided into 4 categories, namely: 1. Financial capital, 2. Physical capital or technology, 3. Human capital. 4. Organizational capital. Reasons that require a company to carry out value chain analysis according to Schmitz (2005) are: (1) Activities in the value chain are often carried out in different parts or divisions so that they are global, (2) some value-added activities in the value chain are profitable and (3) some business actors in the value chain have power over other actors (lead firms).

\section{Research Methods}

The study was conducted in 8 months starting from April to November 2018. The research locations were determined purposefully in West Sumatra, especially in Padang and its surrounding areas. This study uses a descriptive method based on a case study of the application of value chain governance, i.e., i-Ternak in West Sumatra. Observations and surveys include reviewing and gathering information from i-Ternak value chain network activities. The surveys were conducted on several breeders and partner companies to identify and map the value chains of PT MEK input producer companies with partner farmers in Padang and surrounding areas by using questionnaires to obtain data on value chain management, internal and external conditions of the value chain and margin analysis marketing. Respondents were taken randomly, except investors since they were outside of West Sumatra, expert respondents were determined by the nonprobability sampling method, namely by purposive sampling method. The respondents are believed to have expertise and competence in their fields. Expert respondents consisted of internal respondents, namely businessmen and women involved in the company's value chain. External respondents were individuals who have expertise in poultry. The data were collected through individual in-depth interviews with respondents based on their fields of expertise.

The data were analyzed according to the following purposes:

1. The value chain map was analyzed with qualitative descriptive

2. Management of value chain was analyzed by using value chain management determinant based at Gereffi et al. (2005), namely the dynamics of change in value chain governance. Therefore, the identification of typologies from Global value chain governance was needed, with different forms of coordination between companies. Table 2 illustrates some of the dynamics of Global value chain governance, which has a framework focusing on the nature and content of relationships between companies or industries and the power to regulate value chain coordination between key suppliers and buyers

3. Marketing margin

Marketing margin for all actors in the value chain, the highest and lowest margins, cost structure and profit were assessed to know which components have the largest portion using the margin Table according to Prayogo (2010). 
Table 1: The dynamics of global value chain governance

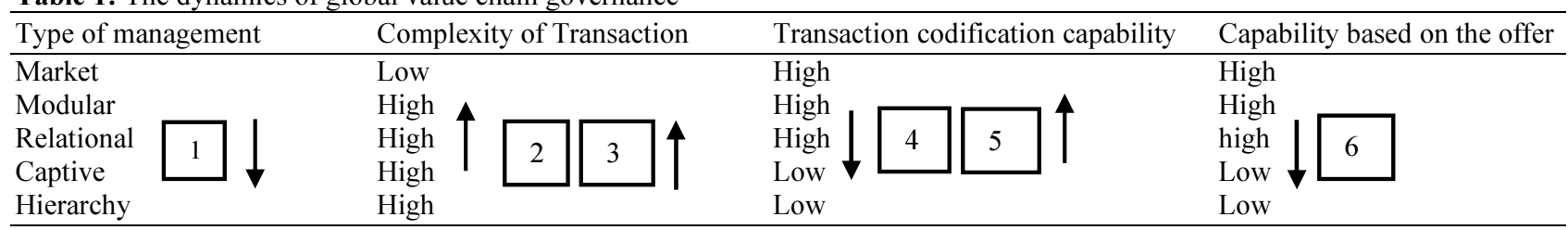

Source: Gereffi et al. (2005)

Table 2: Cattle population in west Sumatra 2008-2017

\begin{tabular}{llllr}
\hline No. & Year & Population & $\begin{array}{l}\text { Growth rate } \\
\text { in number }\end{array}$ & $\begin{array}{r}\% \\
\%\end{array}$ \\
\hline 1 & 2008 & 58,172 & - & \\
2 & 2009 & 71,581 & 0.230506085 & 23 \\
3 & 2010 & 65,933 & -0.07890362 & -8 \\
4 & 2011 & 34,129 & 0.482368465 & -48 \\
5 & 2012 & 38,019 & 0.113979314 & 11 \\
6 & 2013 & 39,903 & 0.04955417 & 5 \\
7 & 2014 & 41,100 & 0.029997745 & 3 \\
8 & 2015 & 37,415 & 0.089659367 & -9 \\
9 & 2016 & 37,415 & 0 & 0 \\
10 & 2017 & 38,863 & 0.038701056 & 4 \\
Average & Growth rate & -1.88193082 & & -1.9 \\
\hline Source & 2017 BPS Livesta
\end{tabular}

Source: 2017 BPS Livestock data

Table 1 illustrates that the dynamics of changes in value chain governance:

1. Increase transaction complexity and reduce supplier competency when dealing with new requests

2. Decrease transaction complexity and increasing ability to codify

3. Provides for a better codification and a de-coded transaction

4. Increase supplier competency while decreasing supplier competency

\section{Results and Discussion}

\section{A. Overview of Research Objects}

Based on the data from the Central Statistics Agency (BPS-2017), domestic beef production in the 2017 period was recorded at 354,770 tons, while the estimated beef demand reached 604,968 tons. There was a very large gap between the needs and availability to fulfill the demand for beef in Indonesia. Meanwhile, the growth of consumption of animal protein, especially beef consumption increased by $15 \%$ per year, but production growth has only increased by $4.5 \%$ per year. The lack of development of the pattern of people's livestock in Indonesia in general and the area of West Sumatra, in particular, was because of the inability to access easy and inexpensive financing sources. The main problems faced by farmers in business development were unbankable farmers and lack of knowledge and technology in livestock.

West Sumatra is one of the Indonesian provinces that develop beef cattle with a population as described in Table 5.
The working method of i-Ternak is internet-based. Today is the era that life can be run with 'a finger' through Android and smartphones. i-Ternak investment program can be accessed through Playstore either by using an Android mobile phone or by directly accessing the i-Ternak web with Google. Some of the advantages of the i-Ternak program are the application of financial technology which is now better known as fintech. Fintech is an innovation in ITbased financial services. It is a combination of financial and technology combined with a touch of modern innovation that can provide digital-based financial services with several classifications including:

- Crowdfunding and peer to peer lending, for example, kitabisa.com

- Payment such as e-wallet

- Investment and financing such as i-Ternak

The i-Ternak program also involves several government programs such as guarantee programs, through insurance, intending to facilitate supervision. Cows should pass the SKKH test, therefore the cowsheds are standardized by the livestock service office and more Islamic nuance which are more directed to sharing economy, namely the attitude of participation in economic activities that create value, independence and prosperity. Public capital that is stored in the form of crude funding can be collected and utilized for the development of beef cattle once it increases community income which in turn will improve welfare.

\section{The Role of i-Ternak Partnership in Forming Information Technology-Based Beef Cattle Chain}

\section{a Value Chain Mapping}

Value chain mapping in the i-Ternak Beef Cattle partnership system is used to determine the value chain pattern, the activities of each chain and the extent of the role of each chain in creating and increasing the value of the company to achieve competitive advantage or better competitiveness. The higher the competitive advantage, the company or breeder will have a higher bargaining position with the related business actors. i-Ternak partnership program involves several parties who have their respective roles in the information technology and financial technology-based beef cattle business value chain. The cooperation scheme in the i-Ternak partnership program is shown in Fig. 1. 
Table 3: The marketing margin of meat in i-Ternak value chain for cattle (Simenthal, Sumba ongol, sacrificial cow or Qurban)

\begin{tabular}{|c|c|c|c|}
\hline Farmer & Simenthal & Sumba Ongol & Qurban \\
\hline Number of cattle & 1 & 1 & 1 \\
\hline Duration to raise the cattle (in a month) & 150 days & 150 days & 150 days \\
\hline Initial Weight $(\mathrm{kg})$ & $448 \mathrm{~kg}$ & $200 \mathrm{~kg}$ & $210 \mathrm{~kg}$ \\
\hline Harvest Weight (kg) & $613 \mathrm{~kg}$ & $337 \mathrm{~kg}$ & $363 \mathrm{~kg}$ \\
\hline$P B B$ & $177 \mathrm{~kg}$ & $137 \mathrm{~kg}$ & $153 \mathrm{~kg}$ \\
\hline \multicolumn{4}{|l|}{ Variable Cost } \\
\hline cow & $20,025,000$ & $9,000,000$ & $8,900,000$ \\
\hline Forage & $4,320,000$ & $2,160,000$ & $2,154 ., 000$ \\
\hline SKKH & 250,000 & 250,000 & 250,000 \\
\hline Assurance + Drugs & 364,000 & 196,000 & 196,000 \\
\hline Total of Variable Cost (IDR) & $24,959,000$ & $11,606,000$ & $11,500,000$ \\
\hline Sale of Cow (IDR) & $27,990,000$ & $15,165,000$ & $13,911,765$ \\
\hline Margin & $3,031,000$ & $3,459,000$ & $2,411,765$ \\
\hline $\mathrm{R} / \mathrm{C}$ Fattening & 1.14 & & \\
\hline \multicolumn{4}{|l|}{ Sharing: (IDR) } \\
\hline i-Ternak $(20 \%)$ & 606,200 & 691,800 & 482,353 \\
\hline Investor $(40 \%)$ & $1,212,400$ & $1,383,600$ & 964,706 \\
\hline Farmer $(40 \%)$ & $1,212,400$ & $1,383,600$ & 964,706 \\
\hline \multicolumn{4}{|l|}{ Farmer Cost (IDR) } \\
\hline Degradation of cowshed \&tool & 53,700 & 53,700 & 53,700 \\
\hline Forage & 50,000 & 50,000 & 50,000 \\
\hline Total Farmer Cost & 103,700 & 103,700 & 103,700 \\
\hline Margin Farmer Cost (613 Kg) & $1,108,700$ & $1,280,900$ & 861,006 \\
\hline Margin per kg Middlemen & 1,808 & 3,801 & 2,372 \\
\hline Cow Purchasing $(615 \mathrm{~kg})$ & $27,990,000$ & $15,165,000$ & $13,911,765$ \\
\hline Income from the sale of cows & $29,705,000$ & $16,200,000$ & $17,424,000$ \\
\hline Collecting cost & 50,000 & $1,035,000$ & $3,512,235$ \\
\hline Decrease of weight, to be $613 \mathrm{~kg}$ & 96,000 & 3,071 & 9,676 \\
\hline Margin & $1,569,000$ & & \\
\hline Margin per kg & 2,560 & & \\
\hline Butchers & & & Mesjid \\
\hline Cow Purchasing (613 kg) & $29,705,000$ & $15,165,000$ & $17,424,000$ \\
\hline Karkas $55 \%(337,15 \mathrm{~kg})$ & & $168,5 \mathrm{~kg}$ & \\
\hline \multicolumn{4}{|l|}{ Price of meat IDR $100,000,-$} \\
\hline Cost of butchering & 150,000 & $16,850,000$ & \\
\hline Income from the sale of cows & $33,700,000$ & $1,685,000$ & \\
\hline Margin & $3,845,000$ & 10,000 & \\
\hline Margin per kg Vendors & 11,404 & & \\
\hline Cow Purchasing (337 kg) & $33,700,000$ & $16,850,000$ & \\
\hline Costs, packaging & 10,000 & 10,000 & \\
\hline Rent & 13,700 & $21,905,000$ & \\
\hline Income from the sale of cows & $43,810,000$ & $4,055,000$ & \\
\hline Margin & $10,086,300$ & 24,065 & \\
\hline Margin per kg & 29,930 & & \\
\hline \multicolumn{4}{|l|}{ Consumers (Restaurant, hotel, catering) } \\
\hline \multicolumn{4}{|l|}{ Production of Processed Meat } \\
\hline The average weight of meat $(\mathrm{kg})$ & 20 & 10 & \\
\hline $\begin{array}{l}\text { Rendement (The total processed products } \\
\text { are divided by the amount of meat) }\end{array}$ & 400 & 200 & \\
\hline Selling Price of Processed Meat (IDR) & 15,000 & 15,000 & \\
\hline \multicolumn{4}{|l|}{ Costs (IDR) } \\
\hline Cow purchasing & $2,600,000$ & $1,300,000$ & \\
\hline Ingredients & $1,500,000$ & 750,000 & \\
\hline Labor & 200,000 & 100,000 & \\
\hline Overhead & 200,000 & 100,000 & \\
\hline Marketing cost & 150,000 & 50,000 & \\
\hline Total Cost & $4,650,000$ & $2,300,000$ & \\
\hline Processed Meat Selling & $6,000,000$ & $3,000,000$ & \\
\hline Margin & $1,350,000$ & 700,000 & \\
\hline Margin per kg (IDR) & 67,500 & 35,000 & \\
\hline
\end{tabular}


Table 4: Marketing margin, share cost and share of the benefits of technology-based beef cattle partnership business i-Ternak

\begin{tabular}{|c|c|c|c|c|c|c|}
\hline \multirow{3}{*}{$\begin{array}{l}\text { No. } \\
1\end{array}$} & \multirow[b]{2}{*}{ Chain-I } & \multirow{2}{*}{$\begin{array}{l}\text { Margin-i (Pr - Pf) } \\
(\mathrm{IDR} / \mathrm{kg})\end{array}$} & \multicolumn{2}{|c|}{ Cost of Chain Sharing-i } & \multicolumn{2}{|c|}{ Profit of Chain Sharing-i } \\
\hline & & & $\mathrm{Bi}$ & Sbi & $\mathrm{Ki}(\mathrm{IDR} / \mathrm{kg})$ & Ski (\%) \\
\hline & Farmer & 1,808 & (IDR/kg) & $(\%)$ & 1,808 & 2.20 \\
\hline 2 & Investor & 1,978 & 170 & 0.20 & 1,978 & 2.42 \\
\hline \multirow[t]{7}{*}{3} & i-Ternak & 982,000 & 82 & 0.10 & 989 & 1.21 \\
\hline & a. Middlemen & 2,961 & 238 & 0.30 & 2,961 & 3.61 \\
\hline & a. Butcher & 11,404 & 245 & 0.30 & 11,404 & 13.91 \\
\hline & b. Vendor & 29,930 & 30 & 0,04 & 29,930 & 36,50 \\
\hline & c. Hotel & 67,500 & 11,625 & 14,17 & 67,500 & 82.32 \\
\hline & d. Restaurant & 67,500 & 11,625 & 14,17 & 67,500 & 51.92 \\
\hline & e. Catering & 67,500 & 11,625 & 14,17 & 67,500 & 51.92 \\
\hline
\end{tabular}

Description: $\mathrm{Bi}=$ Cost of Chain-I, Ki = Profit of Chain-I, Sbi = Cost of Chain Sharing-I, Ski = Profit of Chain Sharing-I

Table 5: i-Ternak partnership value chain management

\begin{tabular}{|c|c|c|c|c|}
\hline No & Partnership management & Attributes & Partnership value & Type of partnership management \\
\hline \multirow[t]{3}{*}{1} & \multirow[t]{3}{*}{ Supplier and i-Ternak } & Transaction complexity & 2.86 (low) & \multirow[t]{3}{*}{ Market } \\
\hline & & Transaction codification capability & 3.66 (high) & \\
\hline & & Capability based on offer & 3.06 (high) & \\
\hline \multirow[t]{3}{*}{2} & \multirow[t]{3}{*}{ Forage Supplier and Farmer } & Transaction complexity & 2.85 (low) & \multirow[t]{3}{*}{ Market } \\
\hline & & Transaction codification capability & 3.14 (high) & \\
\hline & & Capability based on offer & 3.04 (high) & \\
\hline \multirow[t]{3}{*}{3} & \multirow[t]{3}{*}{ i-Ternak and investor } & Transaction complexity & 3.30 (high) & \multirow[t]{3}{*}{ Modular } \\
\hline & & Transaction codification capability & 3.35 (high) & \\
\hline & & Capability based on offer & 3.13 (high) & \\
\hline \multirow[t]{3}{*}{4} & \multirow[t]{3}{*}{ i-Ternak and middlemen } & Transaction complexity & 3,39 (high) & \multirow[t]{3}{*}{ Captive } \\
\hline & & Transaction codification capability & 2.95 (low) & \\
\hline & & Capability based on offer & 2,78 (low) & \\
\hline \multirow[t]{3}{*}{5} & \multirow[t]{3}{*}{ i-Ternak and butcher } & Transaction complexity & 3.06 (high) & \multirow[t]{3}{*}{ captive } \\
\hline & & Transaction codification capability & 2.85 (low) & \\
\hline & & Capability based on offer & 2,62 (low) & \\
\hline \multirow[t]{3}{*}{6} & \multirow[t]{3}{*}{ i-Ternak and slaughterhouses } & Transaction complexity & 3.39 (high) & \multirow[t]{3}{*}{ Modular } \\
\hline & & Transaction codification capability & 3,55 (high) & \\
\hline & & capability based on offer & 3.12 (high) & \\
\hline \multirow[t]{3}{*}{7} & \multirow[t]{3}{*}{ i-Ternak and vendor } & Transaction complexity & 3.14 (high) & \multirow[t]{3}{*}{ Captive } \\
\hline & & Transaction codification capability & 2.78 (low) & \\
\hline & & capability based on offer & 2.80 (low) & \\
\hline \multirow[t]{3}{*}{8} & \multirow[t]{3}{*}{ i-Ternak and Hotel } & Transaction complexity & 3.30 (high) & \multirow[t]{3}{*}{ Captive } \\
\hline & & Transaction codification capability & 2.75 (low) & \\
\hline & & capability based on offer & 2.90 (low) & \\
\hline \multirow[t]{3}{*}{9} & \multirow[t]{3}{*}{ i-Ternak and restaurant } & Transaction complexity & 2.80 (low) & \multirow[t]{3}{*}{ Modular } \\
\hline & & Transaction codification capability & 3.14 (high) & \\
\hline & & capability based on offer & 2.58 (low) & \\
\hline \multirow[t]{3}{*}{10} & \multirow{3}{*}{$\begin{array}{l}\text { Partnership Management } \\
\text { between i-Ternak and catering }\end{array}$} & Transaction complexity & 3.39 (high) & \multirow[t]{3}{*}{ Captive } \\
\hline & & Transaction codification capability & 2.85 (low) & \\
\hline & & Capability based on offer & 2.59 (low) & \\
\hline
\end{tabular}

Source: Research data. Remarks: Results $<3.00=$ low, Results $>3.00=$ high

\section{b. Primary Activity}

Based on Table 5, it can be explained that this collaboration is better integrated, so it can shorten the supply chain and improve the value chain more efficiently. The value chain is formed by various parties having distinct roles. The description of the roles of each value chain is as follows:

\section{Inbound Logistics}

\section{1) $i$-Ternak}

i-Ternak, an organizer of peer to peer lending (Layanan Pinjam Meminjam Uang Berbasis Teknologi
Informasi), is a financial service company that has obtained permission from the Financial Services Authority under the registration No. S-257/NB.213/2018 dated on April 6th, 2018, based on the Financial Services Authority Regulation No. 77/POJK.01/2016 on Information Technology-Based Money Lending and Borrowing Services located at Gedung 828 Ruko Taip Square No 11-12. Jl. H. Taip Kedaung, Pamulang Tangerang Selatan - Banten 15415. It also cooperated with the Ministry of Communication and Information Technology to conduct the i-Ternak partnership program by using technology financial applications. The advantages of farming through i-Ternak are the farmers 
become more experienced (certified), the distribution network becomes more integrated, livestock is healthier and beneficial: Pola Bagi HasilPengendalian Risiko (Livestock Insurance). The management of the business is carried out by PT MEK as a livestock party, which is tasked to purchase the stocks (cows), manage the SKKH test, pay insurance premiums and buy feed concentrates by using investment money from investors.
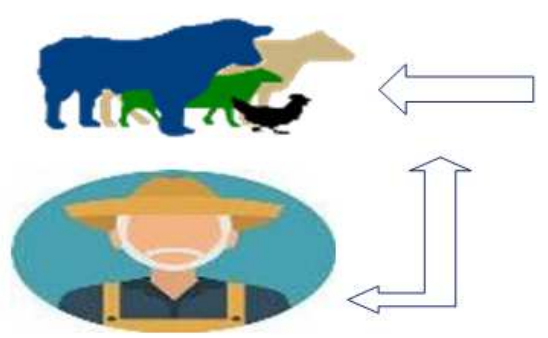

\section{Farmer:}

Empowerment of small farmers;

Implementation and maintenance of i-Ternak products;

Implementation/maintenance of livestock units;

Report the development of livestock units; Harvest revenue sharing reception.

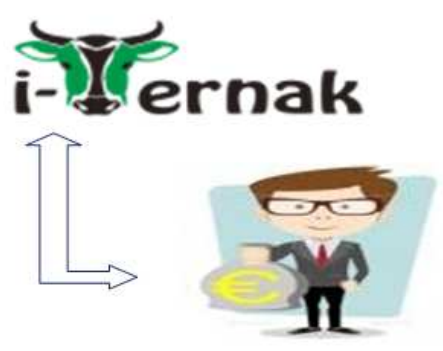

Cloud-based agriculture management software;

Livestock buying;

Harvest selling;

Reporting livestock units development;

Harvest revenue sharing;

Fig. 1: Cooperation scheme of i-Ternak partnership program

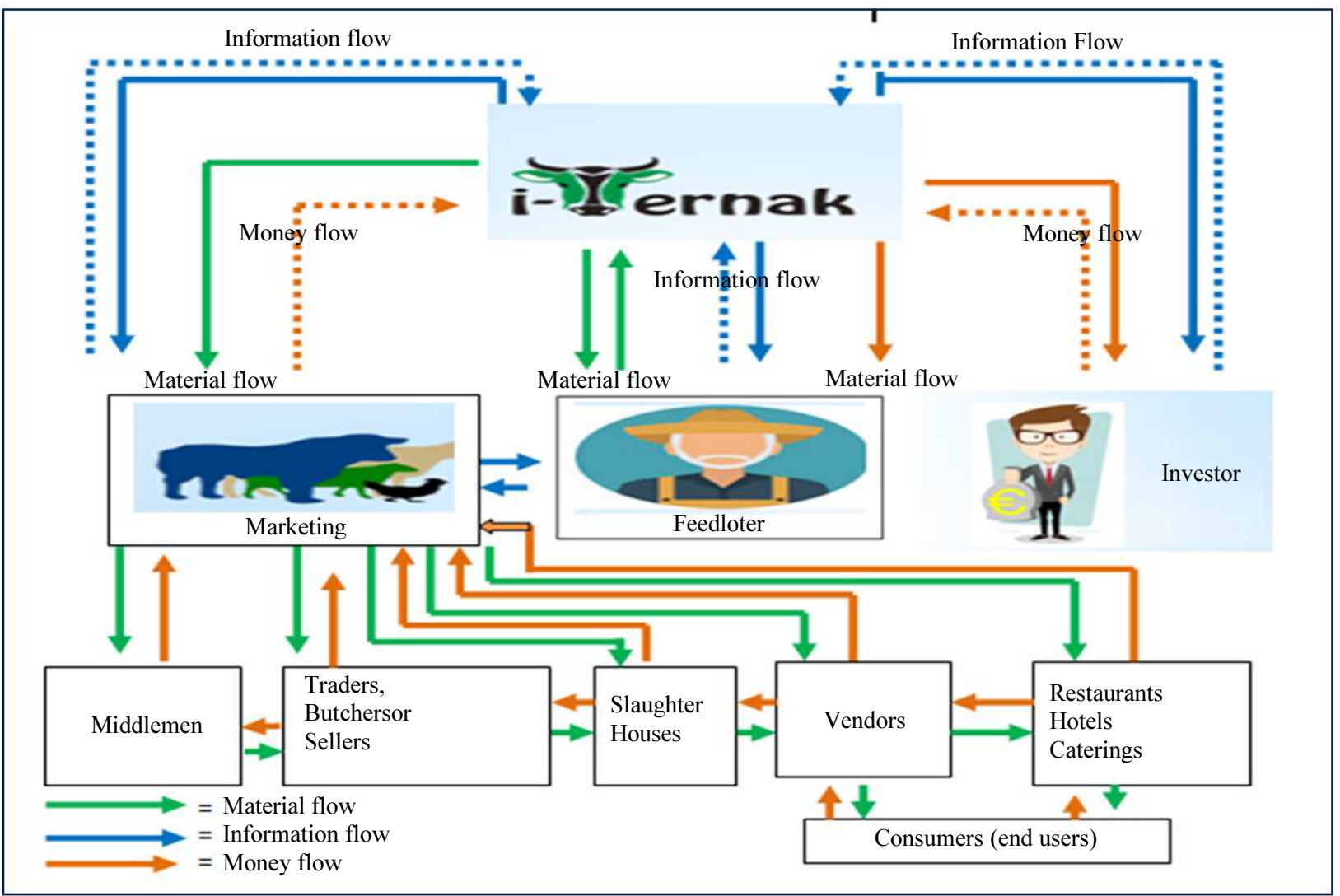

Fig. 2: Supply chain pattern for beef cattle fattening in i-Ternak 


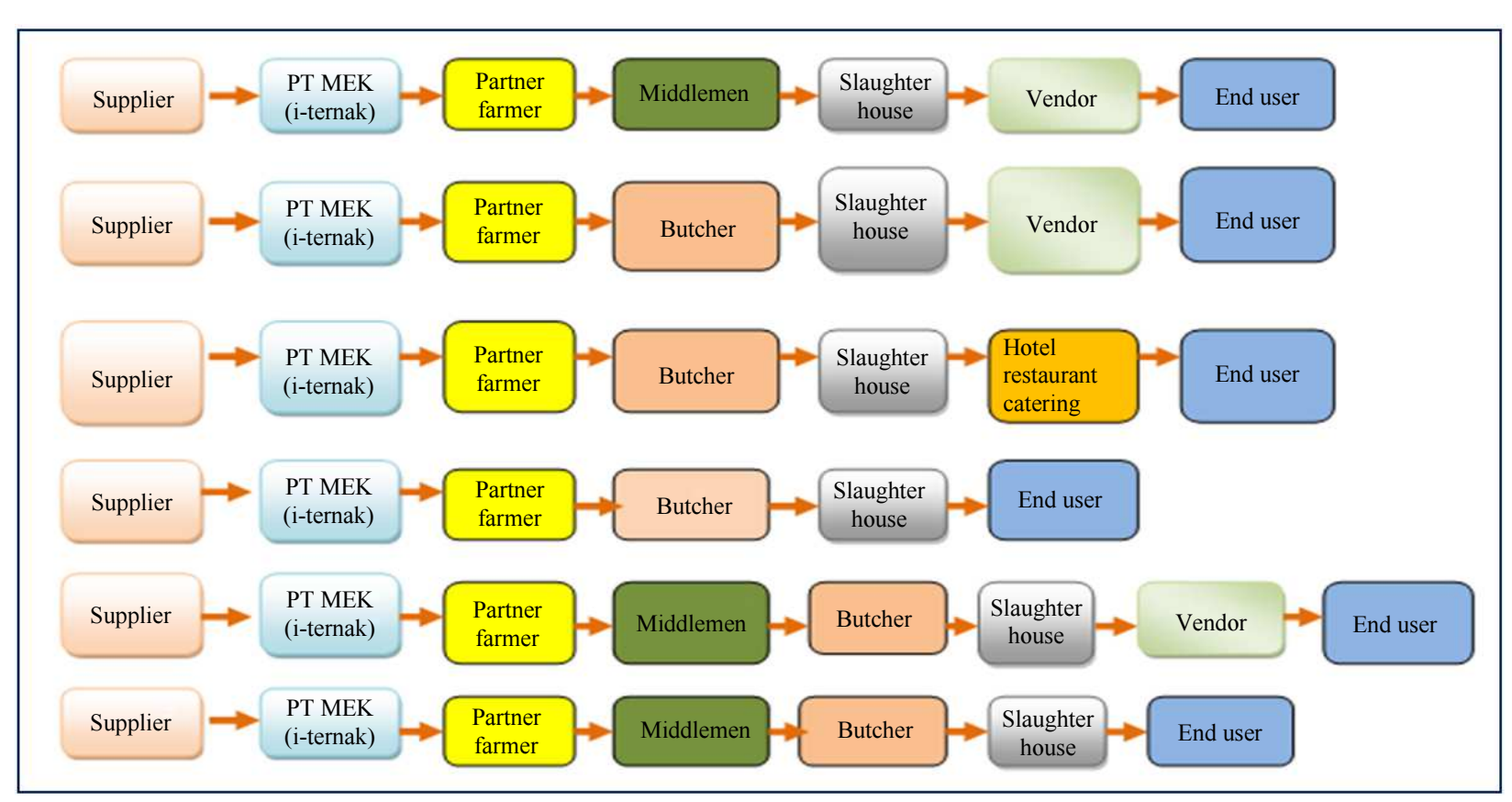

Fig. 3: The pattern of supply chain for beef cattle in i-Ternak partnership

\section{2) Investors}

Investors involved in the i-Ternak beef cattle partnership program are individuals or a group of individuals who are willing to invest their money in an iTernak beef cattle farm, which is received through registration on the i-Ternak website. The obligations of the investors are to register, provide a valid identity and pay the investment costs. The investment costs paid by the investors consist of 4 things, namely: Purchasing Will, Costs for inspecting livestock conditions that will be fattened to get SKKH or Certificate of Animal Health, Payment of Jasindo Insurance Premium and Drug Costs. The rights received are profit-sharing from the profits of livestock with an estimated ROI of $9-24 \%$ per year. Another advantage is that the investors can visit farm locations as a form of agro-tourism and provide social impact by helping small farmers to earn farmers' income so that they can add the number of cows.

\section{3) PT. Minang Ekonomi Kreasi (PT MEK)}

This company is a manager that acts as a supplier of production input. The duties are to supervise farmers and buy back cattle that have been fattened and ready to be 'harvested'. The obligation of PT Mek in this value chain is to buy cattle that will be fattened which usually does not originate from West Sumatra. They are generally purchased from Java and Lampung. Another role of PT Mek is to supply concentrates which costs are included in the investment costs by the investors. The concentrate supplied is a guaranteed concentrate with high quality. It can increase the weight of local cattle at least 0.8 kilograms and 1.8 kilograms per day for eximported cattle such as Simental and Brahman Cross.

During the maintenance period, PT Mek has the obligation to supervise breeders, cattle raised if they are sick and look for markets.

\section{Operation (Production Process of Beef Cattle Fattening)}

\section{1) Breeder}

The breeders who are i-Ternak partners are breeders that are selected and appointed by i-Ternak through a statement of cooperation (commitment), complete facilities and infrastructure for cowsheds, labor, farming experience, education level, cage capacity, eligibility of cowsheds that must obtain standardized letters from the local Livestock Service Office. i-Ternak breeders are spread throughout the cities in West Sumatra Province. Farmers act as producers in the i-Ternak value chain business. The production process is in the hands of farmers, the main obligation is to raise cattle to increase the weight of cattle. The daily weight gain is required not less than 0.5 kilograms for local cattle which consists of Bali cattle, Sumba Ongole, while the daily weight gain for imported cattle such as Simental, Brahman Cross and Limousine must be more than 1.2 kilograms. Farmers are obliged to provide forage in the form of crude fiber while concentrates are provided by PT Mek which is sent twice a week. Each livestock has been assigned the weight of the given concentrate, which is 10 kilograms per day while the forage is given sufficiently. However, the dead cow will be covered by insurance. The 
distribution of results to be obtained by farmers is $40 \%$ of the net income obtained after the cattle are sold. This amount has been determined since farmers are livestock breeders. In this harvest revenue sharing, $40 \%$ goes to farmers, $40 \%$ is for the investors of i-Ternak as the program owners and $20 \%$ is the net income earned. The distribution of the profit is done no later than 2 weeks after harvesting.

\section{Outbound Logistics}

\section{1) Market}

The markets controlled by i-Ternak are:

- Slaughterhouses, butchers, middlemen, hotels, restaurants and catering

In general, the flow pattern of the beef cattle supply chain found in this study is as follows:

\section{Supplier of Cattle $\rightarrow$ producer (Feedloter) $\rightarrow$ Consumer Distributor.}

The managing supply chain management works with other parties, selects supplier feed partners, determines production sales partners as regulated by i-Ternak companies through a mechanism agreed with PT MEK as the manager. The agreement between the supplier and company includes amount, quality and price; and cash payments will be made after the cattle arrive at the cowsheds. The chain resources include physical resources: Farms of partner farmers, extensive land area (adequate), adequate facilities and road access, technology: The application of feed concentrate technology, human resources and capital.

In general, the value chain pattern formed in the iTernak partnership is illustrated in Fig. 2.

The pattern of distribution of beef cattle products is carried out indirectly because those who are i-Ternak consumers are institutional consumers, middlemen and butchers, vendors, hotels, restaurants and catering. Collaborative planning is carried out by the company by involving feeder cattle supplier partners and consumers while the remaining can purchase beef cattle (meat) products from PT MEK. In the supply chain, beef cattle are faced with risks, both internal risks (operational risk and cooperation) and external risk (environmental risk/policy and market risk). Supply chain patterns can be identified as illustrated in Fig. 3 .

\section{The Performance of the Value Chain of Beef Cattle Business based on Financial Technology.}

\section{a. The Performance Creation and Distribution of Marketing Margin}

The main purpose of i-Ternak is to increase domestic meat production to achieve beef self-sufficiency. After this partnership has been held for 2 periods from February 2018 until this research was carried out, several harvests had been carried out. The ability of this partnership to produce profit margins and the acquisition of each chain used can be seen in the marketing margin table as in Table 3.

Based on Table 3, it can be seen that the margins received by each chain involved are varied according to the respective involvement in this partnership. The smallest chain to receive margins from the operational activities of production is i-Ternak, which is only IDR. 982 per kilogram of live weight of cattle or IDR. 606,200 per cow. This figure represents $20 \%$ of the profit received from 1 cow. The cost per cow expenses incurred by i-Ternak is very small, so it is considered insignificant. Even though i-Ternak receives a small profit from the profit of raising cattle, i-Ternak still gets profits from the supply chain going, feed and medicine.

Based on the calculation example for simenthal, the price of feed and other variable costs such as for concentrates, medicines, amounted to IDR. 24,959,000, while farmers purchased an investment package of IDR. $26,000,000$. The investment package of 1 harvest is IDR 20,000,000, 1 concentrate package for a 5-month consumption is $4,200,000$, animal health certificate from the related agency is IDR 250,000 and the cow insurance premium is IDR 196,000 for 6 months. From this input supply, i-Ternak obtained a margin of IDR. 1,041,000. So that for one cow during one period, i-Ternak receives profit sharing of IDR. 606,200 from January to June 2018, while the investors received a profit share of IDR1,212,400 per cow. This investment provides a Return On Investment (ROI) of $4.76 \%$ for the investment period of 6 months for the investors. The agreement between investors and i-Ternak has to invest at least 1 year or as many as 2 periods. Therefore, the return on investment for 1 year is estimated at $9.5 \%$. This ROI level is in accordance with what $\mathrm{i}$-Ternak has to offer on its website, which ranges from $9-16 \%$ per year. The $\mathrm{R} / \mathrm{C}$ of the fattening business is $27,990,000 / 24,959,000=1.14$

The low level of ROI received by the investors is due to the relatively high price for the first period, namely from January to June 2018 , because it coincides with the number of requests that will be maintained to anticipate meat requirements for Eid in June 2018. In the same period, the farmers as producers have the obligation to provide forage (feed containing crude fiber) and to pay labors, with an average cost of IDR. 103,700. The farmers receive profit sharing of IDR $1,212,400$ or $40 \%$ of the profit. The benefits received by each chain can be seen by comparing margins, sharing the costs incurred and sharing the profits received as presented in Table 4.

Based on Table 4, it can be seen that those who receive the biggest share of profits are meat processors such as hotels, restaurants and catering. The significant role of the meat processing chain is to convert fresh meat into products that will be consumed by consumers, so 
they obtain the largest portion of profit with the level of SKi (Profit of Chain Sharing-I) of $51.92 \%$ or IDR 67,500 per kilogram of fresh meat.

In the group of traders, namely, collectors, butchers and vendors, who receive the biggest share of profits are vendors, which is as much as $36.50 \%$. The high income of vendors is due to the large risk faced by the vendors. Sometimes, the meat that has been stocked does not run out in 1 day. This forces vendors to bear the loss of falling prices for meat that has already been frozen. Because in general, Indonesian consumers prefer warm meat instead of meat that has been cooled or frozen. This follows by the butcher as much as $13.61 \%$ or IDR. 29,930 per kilogram of fresh meat.

The share of the costs incurred by each chain is quite small, the lowest cost is borne by vendors, which is as much as IDR. 30,- per kilogram of fresh meat or $0.04 \%$ of the total cost. The highest cost share is IDR 14,117,per kilogram fresh meat issued by restaurants, hotels and catering because they process fresh meat to be products that are ready to be consumed by consumers.

Based on the results of the field observations of breeders' enclosures, the obstacles are uncertainty about feed and quality supplies, the lack of smooth flow of information between i-Ternak and suppliers and breeders, resulting in delays in shipping concentrates as the most important input in the fattening business. To solve this, good value chain management is needed by increasing important variables in managing relationships between chains.

\section{Value Chain Management Performance}

Value chain management performance is needed so that i-Ternak partnership does not fail in continuing their business. The assessment of value chain management performance is carried out by using three key variables in managing the global value chain according to Sturgeon (2004: 57), namely: (1). The complexity of transactions. Increasingly complex transactions require greater interaction between actors in the value chain and form stronger governance compared to simple pricebased markets. Furthermore, complex transactions make it possible to associate with one of three network management patterns. (2). Coded transactions. In some industries, the activity is carried out through codified information so that the data can be easily channeled between partners in the value chain through information technology. If the supplier has the competence to receive and act on the codification of the information and if the codification of the information is known and used in its operation, then the modular value chain is integrated into the process. If they do not, then the steering company may store the function internally, directing it to vertical (hierarchical) integration or outsourcing this function to other suppliers that are tightly controlled and monitored or have certain relationships with suppliers. (3) Supplier competency. The ability to receive and act on information or complex instructions from the steering company requires the supplier's level of competence. Only through these capabilities can complex transfers of information codification (such as on modular networks) or intensive interactions (such as relational networks). If the supplier competencies for that matter do not exist, the steering company must internalize functions (hierarchical) or outsource to other suppliers that are controlled and monitored (captive suppliers).

The results of the calculation of value chain management in i-Ternak beef cattle partnerships which are calculated based on respondents' choice of the value chain management questionnaire by interview method are described in Table 5. The number of respondents is 20 people consisting of 8 farmers, 1 supplier, 1 feed supplier, 2 investors, i-Ternak chief executive officer, head of Livestock Service Office of West Sumatra Province, middlemen, butchers, head of slaughterhouses, restaurant owners, catering owners and heads of the kitchen in hotel X. The results can be seen in Table 5 .

Based on Table 5, it can be seen that the relationship with all chains can be defined based on the opinions of Gereffi et al. (2005). The management of the value chain found in this study was described as follows:

\section{c. Type of Market Management}

This type of market management has the characteristics of low transaction complexity, high codification and high bidding ability. the i-Ternak value chain which has this type of market is the relationship that occurs between i-Ternak and input suppliers: Input of cattle, forage input and drugs. The low complexity of transactions means that the product is expected to be easily understood by suppliers as illustrated in the following table.

The table shows that the management of type market relationships is appropriate to the sources of input as the information that will be exchanged between the suppliers and i-Ternak is simple and can be fulfilled by the suppliers: The information about the type of forage, weight, price and amount needed.

\section{d. Modular Management Type}

This type of management has the characteristics of the three indicator variables, namely the complexity of transactions, codification and ability of high-value offers. This occurs in the i-Ternak chain with investors, as providers of investment packages, in a modular patterned value chain that tends to take full responsibility for fulfilling the product specification desired by the partners. The chain of i-Ternak with slaughterhouses. As the supplier of cattle, i-Ternak must be able to manage the relationship with the slaughterhouses. The 
specifications of the desired product for slaughterhouses must be fulfilled by i-Ternak. Such as the type of cow that is requested, the health condition of the cow, the weight of the cow and the price match. According to Keane (2014), a buyer-supplier interaction can be very complicated due to the high volume of information flowing between chains within a company. This requires high codification and bidding capabilities to maintain interaction between partners. i-Ternakchain with restaurants has a high transaction complexity. The diverse product information requires high product codification capabilities to avoid deviations from meat specifications needed by the restaurants. i-Ternakneeds to have the ability to offer products so that the relationship that occurs can last long and the restaurants would not leave i-Ternak as customers. The modular pattern in the global value chain, the transition from customer to be supplier is relatively easy because the asymmetrical power is relatively low as both the suppliers and buyers work with many partners.

\section{e. Type of Captive Management}

This type of management has high transaction complexity characteristics but has low transaction codification and low bidding ability. According to Sturgeon (2005), the type of captive management signifies that a lower chain (small supplier) tends to depend on a dominant chain. The asymmetrical power relation between suppliers and customers allows iTernak to provide them with special services, which sometimes requires large fees. In this study, this was found in the relationships between i-Ternak and middlemen, i-Ternak with butchers, i-Ternak with vendors, i-Ternak with hotels and i-Ternak with catering. From these relationships, it can be seen that the chains that receive supply are definite markets for i-Ternak. However, all chains have diverse product specifications that need attention from i-Ternak. Therefore, to maintain a long relationship with all of the chains, i-Ternak requires efforts in facing the complex transactions.

\section{Conclusion}

The value chain involved in the partnership of technology-based beef cattle fattening is based on the results of mapping and their roles are:

- $\quad$ i-Ternak, a website manager who offers investment packages that can be purchased by investors according to the requirements required

- Investors, the wider community who want to invest their money in information technologybased beef cattle fattening

- Suppliers of inputs (PT MEK), which provide forage, concentrates and medicines, provide
SKKH and pay Jasindo Insurance management services and buy cows

- Breeders, who already have standardized certificates as production agents who maintain the cows invested

- $\quad$ PT MEK is also the distributor to several traders, namely middlemen, butchers, vendors, hotels, restaurants and catering

The value chain performance based on the acquisition of the margins of each chain is obtained by the largest chain of meat processors such as restaurants, hotels and catering, followed by vendors, middlemen, farmers of iTernak (PT MEK). The investors received an ROI of $4.76 \%$ of the money they invested. The value chain management performance is seen from the type of management formed in each value chain. 3 types of management produce appropriate performance, namely the type of market for i-Ternak partnership with input suppliers, modular types for i-Ternak partnership with investors, slaughterhouses and restaurants while the captive type is found in i-Ternak partnership with middlemen, butchers, hotels, vendors and catering businesses.

\section{Suggestions}

1. Based on the performance of the value chain seen from the margins produced in each chain, the performance is still too low and uneven. The management of supply chains is needed to improve to reduce production costs so that the overall margin can be increased

2. The inefficient use of financial technology causes input supply to face obstacles. The implementation of a more comprehensive technology for all the value chains involved is necessary to increase

3. This research requires further improvement in the use of information technology that can monitor website-based production processes

\section{Acknowledgement}

This research was supported financially by the Ministry of Research, Technology and Higher Education of the Republic of Indonesia on March 12, 2018 under the skim of Percepatan Guru Besar with the following Contract Number: 26/UN.16.17/PP.RD/LPPM/2018. We thank our Andalas University colleagues for providing valuable insight and expertise which helped complete this research.

\section{Author's Contributions}

Dwi Yuzaria: Project conceptualization, research planning and writing. 
Basril Basyar and Rusjda Khairati: Data collection and interpretation.

\section{Ethics}

This research has been approved by the Commitee of Ethics of the Faculty of Agriculture of Andalas University Padang, Indonesia and therefore, no ethical issues may arise after the publication of this research.

\section{References}

Barney, J.B. and D.N. Clark, 2007. Resource-Based Theory Creating and Sustaining Competitive Advantage. 1st Edn., OUP Oxford, ISBN-10: 0199277680, pp: 316.

Dahlia, M.P. and U.S. Dian, 2015. Pengaruh kompetensi entrepreneur, penggunaan teknologi informasi, inovasi terhadap keunggulan bersaing menuju asean economic community. (Survei pada industri tenun sutra di provinsi selawesi selatan dan sulawesi barat). Proseding of the Peningkatan Daya Saing dalam Menghadapi Asean Economic Community, (AEC' 15), Himpunan Mahasiswa Pascasarjana Fakultas Ekonomi and Bisnis-Universitas Padjadjaran.

David, F.R., 2006. Manajemen strategis: Konsepkonsep. Penerjemah Ikhsan Setiyo, Penerbit Salemba Empat, Jakarta.
Gereffi, G., J. Humphrey and T. Sturgeon, 2005. The governance of global value chains. Rev. Int. Polit. Economy, 12: 78-104. DOI: $10.1080 / 09692290500049805$

Keane, J., 2014. Global value chain analysis: What's new, what's different, what's missing? Research Fellow, International Economic Development Group.

Porter, M.E., 1998. Competitive Advantage: Creating and Sustaining Superior Performance. 1st Edn., Free Press, New York, ISBN-10: 0684841460, pp: 592.

Prayogo, D., 2010. Anatomy of conflict between corporation and local community in a geothermal industry in West Java. Makara Seri SosialHumaniora, 14: 25-34.

DOI: $10.7454 / \mathrm{mssh} . v 14 \mathrm{i} 1.568$

Salin, V., 2000. Information technology and cattle-beef supply chains. Am. J. Agric. Econ. DOI: $10.1111 / 0002-9092.00107$

Schmitz, H., 2005. Value Chain Analysis for PolicyMakers and Practitioners. 1st Edn., International Labour Organization, ISBN-13: 9221177386, pp: 73.

Shipley, D. and C. Egan, 1992. Power, conflict and co-operation in brewer-tenant distribution channels. Int. J. Service Industry Manage., 3: 44-62. DOI: $10.1108 / 09564239210019478$

Sturgeon, T.J., 2005. Conceptualizing integrative trade: The global value chains framework. 